
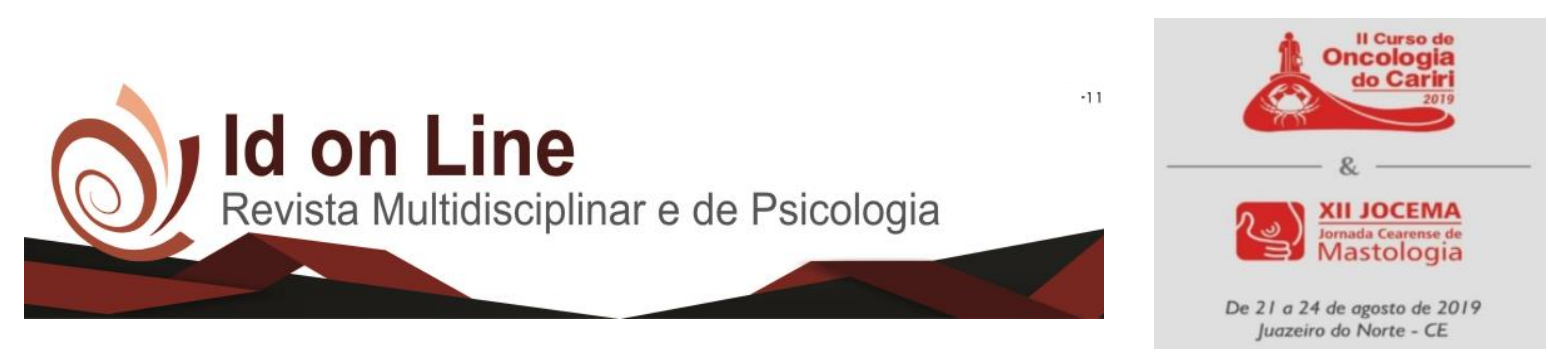

DOI: 10.14295/idonline.v13i46.1993

Resumo

\title{
RELATO DE CASO DE PACIENTE COM DOENÇA DE BOWEN
}

\author{
Bruna Raynara Novais Lima ${ }^{1}$; Grecia Oliveira de Sousa ${ }^{2}$; Rivania Beatriz Novais Lima ${ }^{3}$; \\ André Alencar Moreira ${ }^{4}$
}

Introdução: A Doença de Bowen (DB) é um carcinoma espinocelular in situ com lesão única eritematosa de área escamosa ou crostosa que cresce irregularmente com limites definidos em pele ou mucosas. É mais frequente na população branca com uma incidência de cerca de 1,42/1.000 tendo grande prevalência em idosos (REIZNER et al.,1994). Sugere-se que possui relação com a exposição solar crônica ou arsênica em águas contaminadas (JAMES; BERGER; ELSTON, 2007). Embora rara, existe a sua variável pigmentada. O tratamento da DB é principalmente com a excisão cirúrgica (ROTTA, 2008). Objetivos: Relatar caso de paciente com DB. Destaca-se o tempo de evolução de 23 anos da doença. Relato De Caso: A.S.P., sexo feminino, 38 anos, parda, apresentou-se no ambulatório do Hospital Maternidade São Vicente de Paulo de Barbalha-CE, queixando-se de queimação e prurido associados a uma lesão já diagnosticada por biópsia. Relatou o surgimento de um sinal há 23 anos, semelhante a uma pápula, localizado à direita na região lombar, com coloração mais clara que a atual lesão. Após o escurecimento e expansão do sinal, há 18 anos, iniciaram sintomas frequentes, como prurido, queimação e liberação de pequena quantidade de secreção incolor, inodora e viscosa; a paciente referiu a utilização de medicação tópica desconhecida durante esse período até que realizou uma biópsia há 1 ano, detectando a DB. Observou-se uma lesão hiperermiada, crostosa, com bordas irregulares, hipercrômica e com dimensão 9x6 cm. Como fator de risco A.S.P. residiu em zona rural durante a infância e adolescência, tendo constante exposição solar na região da lesão; nega história pessoal e familiar de câncer. Conclusão: Apesar da paciente não apresentar como fator de risco a cor da pele e a idade mais prevalentes da doença, a exposição solar sofrida durante a juventude estimulou o surgimento da DB. Segundo o INCA (2006), a exposição cumulativa e excessiva nos primeiros $10 / 20$ anos de vida influencia muito nos riscos da pessoa desenvolver câncer de pele. Inicialmente, a hipótese diagnóstica era de uma pápula, com o avançar do caso e a obtenção da biópsia e do laudo histopatológico, foi detectada a DB. Assim, foi indicado o tratamento cirúrgico para DB com a ressecção da lesão mantendo margens de segurança. Devido seu lento crescimento e sua característica variada, essa neoplasia possui um diagnóstico tardio (CAMERON et al., 2010). Assim, é fundamental melhorar a prevenção e a rápida detecção dessa enfermidade.

Palavras-Chave: Doença de Bowen; Exposição solar ; Carcionoma in situ;

\footnotetext{
1Discente do curso de medicina da Universidade Federal do Cariri. brunajuace@gmail.com;

2 Discente do curso de medicina da Universidade Federal do Cariri. grecia.oliveirasousa@ gmail.com;

${ }^{3}$ Discente do curso de medicina da Faculdade de Medicina do Juazeiro. rivania.bnovais@ gmail.com;

${ }^{4}$ Professor orientador formado em medicina na Universidade Federal do Ceará com residência em cirurgia geral na Universidade Federal da Bahia e residência em cirurgia plástica pelo Instituto Dr. José Frota. dr.andrealencar@ gmail.com.
}

9 Id on Line Rev. Mult. Psic. V.13, N. 46 p. 9-10, 2019 - ISSN 1981-1179 EDIČÃO ESPECIAL: ANAIS DO II CURSO DE ONCOLOGIA DO CARIRI E XII JOCEMA - JORNADA CEARENSE DE MASTOLOGIA. JUAZEIRO DO NORTE, 21 A 24 DE AGOSTO DE 2019. 


\section{Referências}

CAMERON, Alan et al. Dermatoscopy of pigmented Bowen's disease. Journal Of The American Academy of Dermatology, [s.1.], v. 62, n. 4, p.597-604, abr. 2010. Elsevier BV. http://dx.doi.org/10.1016/j.jaad.2009.06.008.

INCA. Exposição Solar: radiação ultravioleta. In: INCA. A situação do câncer no Brasil. Rio de Janeiro: INCA, 2006.

JAMES, W.D; BERGER, T.G.; ELSTON, D.M. Andrews. Doenças da Pele. Dermatologia Clínica. Rio de Janeiro: Elsevier; 2007.

REIZNER, George T. et al. Bowen's disease (squamous cell carcinoma in situ) in Kauai, Hawaii: A population-based incidence report. Journal Of The American Academy Of Dermatology, Rosemont, v. 31, n. 4, p.596-600, 31 out. 1994. Mensal.

ROTTA, Osmar. Guia de Dermatologia, Clínica Cirúrgica e Cosmiátrica. São Paulo: Manole, 2008. 